Ann. Biol. anim. Bioch. Biophys., 1979, 19 (3 A), 689-693.

\title{
The appearance of new electrical properties in the plasma membrane of ram spermatids
}

par J. L. COURTENS

Station de Physiologie de la Reproduction, INRA, Nouzilly, 37380 Monnaie, France.

Summary. The « en bloc » staining of ram spermatids with electronegative colloidal iron at $\mathrm{pH} 9$ caused particle precipitation only on the portions of plasma membrane covering both the postacrosomal lamina and the perinuclear ring. This area of the plasma mem brane, implicated in fusion with the oocyte, was characterized by unique electrical properties appearing in the testis.

\section{Introduction.}

Morphological evidence (Fawcett, 1975), as well as differences in the biochemical composition of the plasma membrane, indicate that there are specialized zones on the spermatozoon cell surface (Koehler, 1978). Some of the components of this cell surface are specific to the male germ cell line (Gachelin ef al., 1976); they may be found all over the spermatozoon or only on the flagellum, around the mid-piece and on the subacrosomal zone of the plasma membrane (Millette and Bellve, 1977). This paper reporting ram spermiogenesis, describes the appearance and maintenance of special electrical properties of that portion of the plasma membrane covering the postacrosomal region of the sperm head and implicated in gamete fusion during fertilization.

\section{Material and methods.}

Pieces of testis were fixed for 10 to 24 hrs with 1 to 5 p. 100 freshly depolymerized formaldehyde (Millonig and Bosco, 1967) in $0.07 \mathrm{M}$ phosphate buffer at $\mathrm{pH} 7.4$. The pieces were then washed for $24 \mathrm{hrs}$ in the buffer and for $1 \mathrm{~min}$. in distilled water before being incubated for 24 hrs at $4^{\circ} \mathrm{C}$ in electronegative colloidal iron at $\mathrm{pH} 9,10$ or 11 , according to Puvion and Banquet (1971). After washing for $1 \mathrm{hr}$ at 4 o $\mathrm{C}$ with buffered solutions of the same $\mathrm{pH}$ and composition (iron excepted) as those of the incubation medium, the pieces were dehydrated and embedded in epon.

Control blocks were either acetylated for $4 \mathrm{hrs}$ according to Lison (1953), deaminated for $1 \mathrm{hr}$ according to Lillie (1954), or fixed with 4 p. 100 glutaraldehyde in $0.1 \mathrm{M}$ phosphate buffer at $\mathrm{pH}$.7.4 before being incubated in the colloidal iron solution. 
Ultrathin sections were observed without post-staining using a Philips EM 300 electron microscope. The stages of spermiogenesis were evaluated according to Clermont and Leblond (1955).

\section{Results.}

With the technique used, the only cellular component stained at $\mathrm{pH} 9$ was the plasma membrane covering the postacrosomal lamina of old spermatids and testicular spermatozoa (fig. 3). The contrast progressively developed backwards during stage 12 (fig. 1) owing to the forming postacrosomal lamina (fig. 2). In addition, the membrane covering the perinuclear ring was stained from stage 10 to the end stage 12 (figs. 1,2 ), and was unstained when the perinuclear ring disappeared in stage 13 ; the portion of membrane covering the postnuclear band was not stained (fig. 2). Staining intensity was lower in tissues incubated at $\mathrm{pH} 10$ and was zero after incubation at $\mathrm{pH} 11$.

Controls : «en bloc » acetylation (fig. 4) or nitration, as well as glutaraldehyde fixation, abolished membrane colloidal iron binding.

\section{Discussion.}

According to Puvion and Banquet (1971), the mean diameter of electronegatively charged colloidal iron particles does not permit their penetration into intact cells. Thus, electronegative colloidal iron may be used as an extra-cellular tracer that binds the electropositively charged basic residues according to the $\mathrm{pH}$ of the incubation medium.

The absence of staining observed in the present study after glutaraldehyde fixation, nitration, or acetylation indicated that proteins were involved in colloidal iron binding. In this experiment using paraformaldehyde as a reversible fixation (Scott et al., 1968), the fact that good binding could only be obtained with a $\mathrm{pH}$ lower than or equal to 10 indicated that there may be many more basic residues than acidic ones in the stained regions of the membrane. The most basic residues, arginine and lysine (Puvion and Banquet, 1971 ; Ganter and Jolles, 1969), have not been observed in spermatid plasma membranes after staining for lysine (Courtens and Loir, 1975) or for arginine (Loir and Courtens, 1979 ; Courtens, 1978a).

With these techniques, lysine residues were only found in some spermatid organelles. Of these, the previously described postnuclear band (Courtens et al., 1976),

FIG. 1, 2, 3. - Cells fixed with formaldehyde and stained « en bloc » with negatively charged colloidal iron at $\mathrm{pH}$ 9. Portions of the plasma membrane covering both the perinuclear ring (pnr) and the postacrosomal lamina (Id) are stained. The membrane covering the acrosome (Ac) and the postnuclear band (pnb) is not labelled. Fig. $1: \times 67000$ mid-stage 12 spermatid. Fig. $2: \times 48000$ end of stage 12. Fig. $3: \times 50000$ testicular spermatozoon.

FIG. 4. $-\times 42000$; testicular spermatozoon fixed with formaldehyde and acetylated prior to staining with colloidal iron. The plasma membrane covering the postacrosomal lamina (Id) is not labelled. 

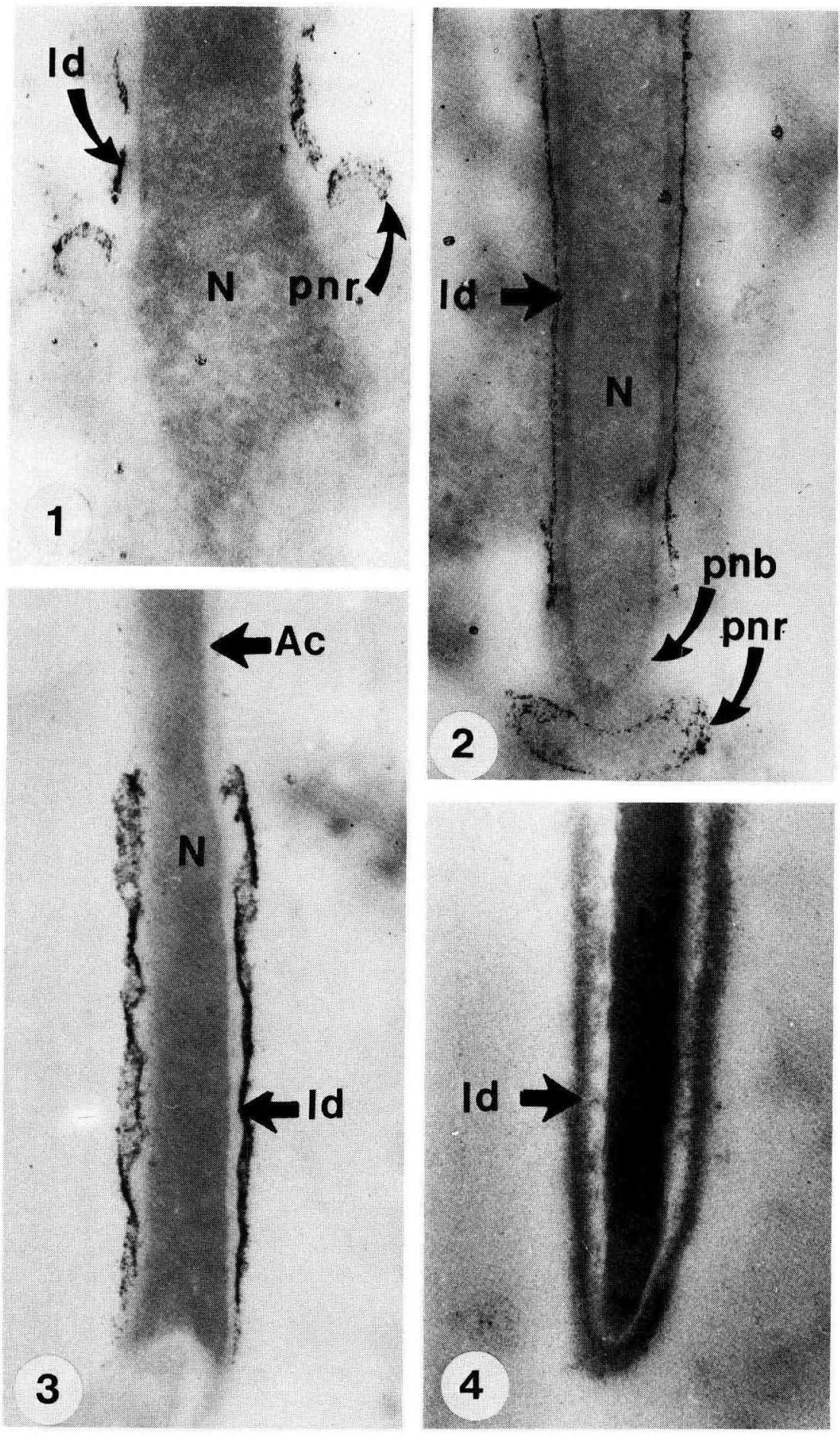
perinuclear ring and postacrosomal lamina were nearest to the stained portions of the plasma membrane. This observation suggested at least three hypotheses to explain the binding of electronegatively charged colloidal iron to the plasma membrane :

1) the plasma membrane covering the perinuclear ring and postacrosomal lamina may be rich in basic residues such as asparagine, glutamine or histidine ( $\mathrm{pK}=9.8$, 9.5 and 9.2, respectively) and/or very poor in acidic residues. This hypothesis does not explain why the plasma membrane covering the perinuclear ring lost its binding affinity when the ring disappeared;

2) the electropositive charge of underlying organelles, i. e. the postacrosomal lamina and the perinuclear ring, might be sufficient to attract negatively charged colloidal iron through the plasma membrane;

3) components of the postacrosomal lamina and perinuclear ring might closely penetrate the plasma membrane in some places.

The last explanation is plausible since regularly-spaced knobs have been observed on the surface of the postacrosomal lamina and the perinuclear ring in both freezeetched specimens and ultrathin sections (Rattner and Brinkley, 1972 ; Koehler, 1966, $1970)$; they are very evident when the organelles are occasionally detached from the plasma membrane (Courtens, 1978b). The present observations do not allow a more definite explanation ; nevertheless, it appears that that portion of the spermatid which, in the spermatozoon will be involved in gamete fusion (Yanagimachi and Noda, 1970), has original electrical properties. These properties may be correlated with a special chemical composition or with the appearance of fertilization sites in the plasma membrane. Recent investigations indicate that they are unmodified in ram spermatozoa taken from both the epididymis and the female genital tract (Courtens and Delpech, 1979).

Reçu en novembre 1978.

Accepté en janvier 1979.

Acknowledgements. - I wish to thank Dr. M. Courot and Dr. M. Loir for their helpful criticism of the manuscript. The technical assistance of Mr. M. Terriot is gratefully acknowledged.

Résumé. La coloration en bloc des spermatides de bélier par le fer colloïdal électronégatif à $\mathrm{pH} 9$ révèle exclusivement les portions de membrane plasmique qui recouvrent la lame postacrosomique et l'anneau périnucléaire. Cette zone membranaire impliquée dans la fusion des gamètes présente des propriétés électriques particulières.

\section{References}

CLERMONT Y., LEBLOND C. P., 1955. Spermiogenesis of man, monkey, ram and other mammals as shown by the periodic acid Schiff technique. Am. J. Anat., 96, 229-253.

COURTENS J. L., LOIR M., 1975. Mise en évidence par cytochimie ultrastructurale de l'évolution des organites cytoplasmiques contemporaine de la perte des histones somatiques au cours de la spermiogenèse du bélier. J. Microscopie, 24, 259-270. 
COURTENS J. L., COUROT M., FLÉCHON J. E., 1976. The perinuclear substance of boar, bull, ram and rabbit spermatozoa. J. Ultrast. Res., 57, 54-64.

COURTENS J. L., 1978a. Cyfochimie ultrastructurale de la spermiogenèse du bélier. Introduction à l'étude de quelques facteurs déterminant la differenciation des structures de la tête du spermatozoïde. Thes. Univ. Paris VI.

COURTENS J. L., 1978b. Morphogenesis of posfacrosomal cytoplasm in the spermatid head. Experimental study of hypophysectomized and testosterone injected rams. Ann. Biol. anim., Bioch. Biophys., 18, 1455-1461.

COURTENS J. L., DELPECH S., 1979. Modifications in the plasma membranes of epididymal ram spermatozoa during maturation and incubation in utero (submitted).

FAWCETT D. W., 1975. The mammalian spermatozoon. A review. Develop. Biol., 44, 394-436.

GACHELIN G., FELLOUS M., GUENET J. L., JACOB F., 1976. Developmental expression of an early embryonic antigen common to mouse spermatozoa and cleavage embryos, and to human spermatozoa : its expression during spermatogenesis. Develop. Biol., 50, 310-320.

GANTER P., JOLLES G., 1969. Histochimie normale et pathologique. Gauthiers-Villars, Paris.

KOEHLER J. K., 1966. Fine structure observations in frozen etched bovine spermatozoa. J. Ultrost. Res., 16, 359-375.

KOEHLER J. K., 1970. A freeze etching study of rabbit spermatozoa with particular reference to head structures. J. Uitrast. Res., 33, 598-614.

KOEHLER J. K., 1978. The mammalian sperm surface : studies with specific labelling techniques. Int. Rev. Cytol., 54, 73-105.

LOIR M., COURTENS J. L., 1979. Nuclear reorganization in ram spermatids. J. Ultrast. Res. (In press).

LILLIE A. L., 1954. Histopathologic techniques and practical histochemistry. The Bakiston Co New York, Toronto.

LISON L., 1953. Histochimie ef cyfochimie animale. Gauthiers-Villars, Paris.

MILLETTE C. F., BELLVE A. R., 1977. Temporal expression of membrane antigens during mouse spermatogenesis. J. Cell. Biol., 74, 86-97.

MILLONIG G., BOSCO M., 1967. Some remarks on paraformaldehyde as fixative. J. Cell. Biol., 35 , 177.

PUVION E., BANQUET P., 1971. Cylochimie ultrastructurale des groupements de point isoionique élevé. Application à la mise en évidence des protéines basiques. J. Microscopie, 12, 171-184.

RATTNER J. B., BRINKLEY B. R., 1972. Ultrastructure of mammalian spermiogenesis. III. The organisation and morphogenesis of the manchette during rodent spermiogenesis. J. Ultrast. Res., 41, 209.

SCOTT J. E., DORLING J., STOCKWELL R. A., 1968. Reversal of protein blocking of basophilia on salt solutions; implications in the localization of polyanions using alcian blue. J. Histochem. Cytochem., 16, 383-386.

YANAGIMACHI R., NODA Y. D., 1970. Ultrastructural changes in the hamster sperm head during fertilization. J. Ulifrast. Res., 31, 465-485. 